\title{
AN OBSERVATIONAL WORKPLACE STUDY OF CARDIOVASCULAR VARIABLES IN AIR TRAFFIC CONTROLLERS
}

\author{
Darius Ereminas \\ Department of Environmental and Occupational Medicine, Kaunas University of Medicine \\ E-mail:ereminas@caa.lt
}

Received 14 January 2009; accepted 5 May 2009

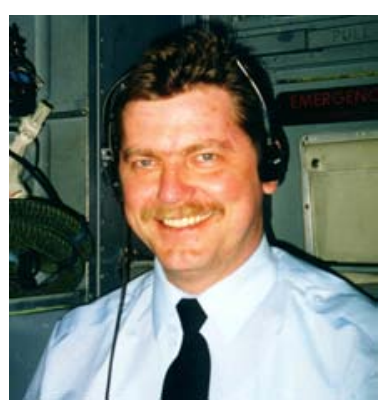

\begin{abstract}
Darius EREMINAS, Dr
Date and place of birth: 1968, Kaunas, Lithuania.

Education: 1992 - Kaunas University of Medicine.

Affiliations and functions: 1994 - resident fellowship in Psychiatric Clinic of Kaunas University of Medicine. 1994-2003 - lecturer at Antanas Gustaitis Aviation Institute of Vilnius Gediminas Technical University; 19982003 - lecturer at the Department of Environmental and Occupational Medicine at Kaunas University of Medicine, 2003-2007 - head of the Department of Aviation Technologies at Antanas Gustaitis Aviation Institute.

Professional membership: member of Aerospace Medical Association and Lithuanian Aviation Medicine Association.

Research interests: labour psychophysiology, aircrew working environment, selection of aircrew members. Publications: author and co-author of more than 16 publications.

Present position: head of Aviation Medicine Department at Civil Aviation Administration.
\end{abstract}

\begin{abstract}
The effects on health due to stress at work may be very different, depending on age, lifestyle, working experience, motivation, physical and mental health, and many other factors. The main objective of this study is to explore the performance of psycho-physiological effects on the air traffic control staff employed at the state enterprise Oro Navigacija.
\end{abstract}

Keywords: air traffic control, psycho-physiological effects, workload.

\section{Introduction}

The International Labour Organisation (ILO) recognises the profession of air traffic controllers as stressogenic (Costa 1995). Sources of stress at their work are as follows:

- performance factors (number of aircraft operated, number of conflicts, lack of time, equipment used, etc.);

- $\quad$ organisational factors (shift work, poor working conditions, etc.).

Stress caused health effects may be different, depending on age, lifestyle, work experience, motivation, physical and mental health, and many other factors. However, many studies have shown the existence of a link between the work of air traffic controllers and the symptoms caused by stress: chronic fatigue, headache, digestive disorder, cardiovascular disorder, etc. (Smith
1990; Farmer et al. 1990). The data published in the scientific literature on health effects by the air traffic controllers work are contradictory, and more investigations is needed. No research on this subject has been performed in Lithuania.

The aim of this study is to explore the psychophysiological effects on air traffic controllers employed in the state enterprise "Oro Navigacija".

These are the main objectives of the study:

1. Assess and analyse the psycho-physiological changes that occur in air traffic controllers (systolic and diastolic arterial blood pressure and heart rate) during the working day.

2. Develop a strategy to improve the working conditions for air traffic control staff and prepare recommendations to combat fatigue and damage to health at work. 


\section{Literature data}

The members of an air traffic control staff are a high performance team assigned with specific requirements: high quality of professional knowledge and specific expertise in a very specific field of cognitive and communicational skills. The American scientists H. L. Ammerman and D. K. Bergen identified six operating characteristics: monitoring air traffic, controlling air traffic, solving conflicts between aircrafts positions, planning and routing flights, evaluating the effect of wind in the sector, and managing situational resources in the scientific study "FA air traffic control operations concepts"(Ammerman et al. 1987). It is obvious that not only the number of aircraft operated, but also by the quantity and complexity of tasks handled determines the air traffic controller's workload. The study also identifies the main sources that cause air traffic controllers psychophysiological tension at their work (Costa 1995).

The cardiovascular reactivity survey conducted by $\mathrm{R}$. Rose and colleagues from the University of Texas in 1994 showed that over 20 years of professional activity about $17 \%$ of the 218 air traffic controllers developed arterial hypertension (Ming et al. 2004).

Eighty Linate airport air traffic controllers participated in the study "Studio delle Pressioni Ambulatoriali delle Loro Associazioni (PAMELA)" performed in Milan in 1998. The main objective of the study was to assess the stress effects on the arterial blood pressure of members of the air traffic control staff. The report stated that air traffic controllers' arterial blood pressure fluctuated slightly and was not statistically different from the arterial blood pressure fluctuations within the control group. This fact proves the good professional training and stress management among the air traffic controllers who participated in the study (Sega et al. 1998).

The psycho-physiological changes caused by the intense workload can be measured with various non- invasive methods. The following measurement methods can provide the necessary data: heart function-electrocardiography, muscle work registration-electromyography, assessment of bioelectric activity in brain-electroencephalography, frequency of eye blinking, measurement of eye pupil diameter, etc (Rose et al. 1982).

\section{Cohort and methods}

1. The cohort investigated was the group of air traffic controllers employed by the state enterprise "Oro Navigacija" (Air Navigation). A total of 24 air traffic controllers work in the tower, and $19(79.2 \%)$ of them agreed to participate in the study. The regional flight control centre at the aforementioned enterprise employs a total of 30 staff members, and $21(70 \%)$ of them agreed to take part in the analysis.

2. The investigation of psycho-physiological human reactions was carried out by non-invasive measurement of both systolic and diastolic arterial blood pressure and also pulse rate during the working day. For this purpose, the portable pulse monitor Mini-Torr Plus (U.S.A.) was used. The device was calibrated at the factory with the possible error being only $\pm 3 \mathrm{mmHg}$ or $2 \%$ for blood pressure and up to $2 \%$ for pulse rate. Data collection was started at the beginning of the working day and continued in 2-hour intervals.

\section{Results and discussion}

The results of the study proved the blood pressure and heart rate can increase temporarily due to work related physiological and psychological stress (Costa 1993). Arterial systolic pressure is called the highest blood pressure during systole. The variation of arterial systolic blood pressure of air traffic controllers is shown in figure 1 .

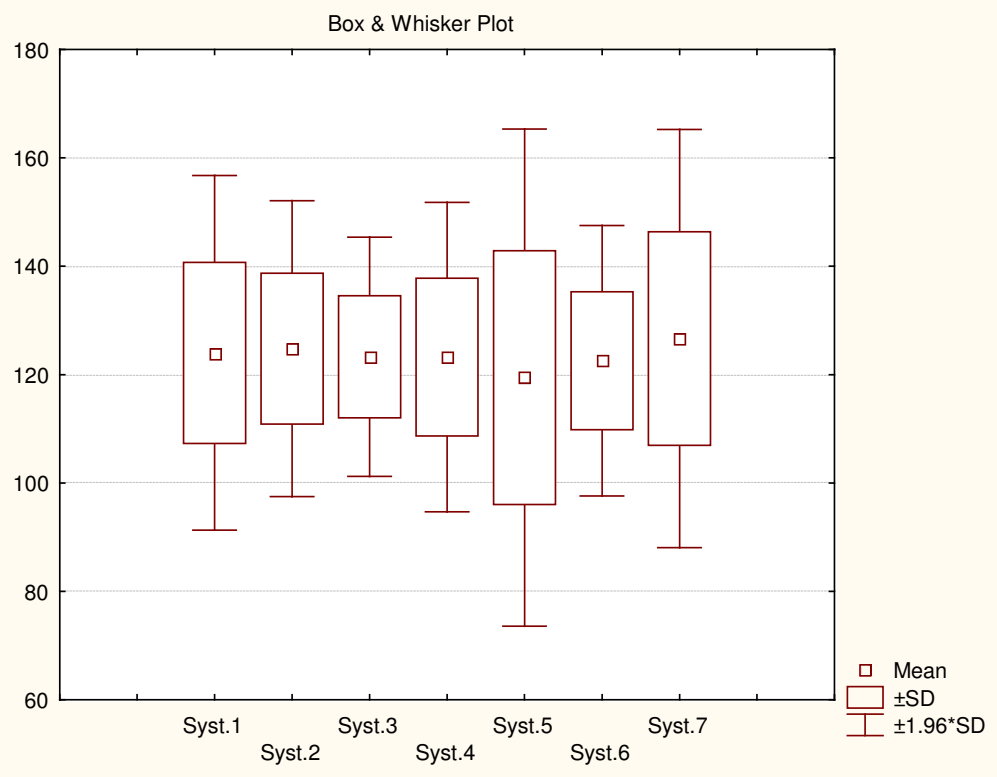

Fig 1. Variation in arterial systolic blood pressure 
The fluctuation in arterial systolic blood pressure during the workday was in the normal range. A part of hypertensive sizes was identified: $14.7 \%$ in the first measurement, $13.6 \%$ in the second measurement, $8.9 \%$ in the third measurement, $10.7 \%$ in the fourth measurement, $9.5 \%$ in the fifth measurement, $10.7 \%$ in the sixth measurement and $15 \%$ in the seventh measurement. The average was $11.9 \%$. The rate of increased blood pressure was similar in size in all measurements. These reactions are not statistically significant, as there is no established correlation between arterial systolic blood pressure and everyday professional activities.

Class 3 medical certification for air traffic controllers requires normal blood pressure. During the analysis of the relationship between blood pressure and age, an increase in blood pressure was noticed in the group of participants at the age of 45-55. Figure 2 presents relationship between age and arterial systolic blood pressure; measurements were taken at the beginning of the working day, before any effects related to work stress were expected.

These results indicate a direct relationship $(r=0.35$, $\mathrm{P}<0.05)$ between age and arterial systolic blood pressure. This is a warning sign showing the need for the implementation of anti-hypertensive measures.

A critical limit of 23 years of professional activity, after which cases of arterial hypertension appear, was found in this study. This argument is illustrated by figure 3.



Fig 2. Age and arterial systolic blood pressure dependence

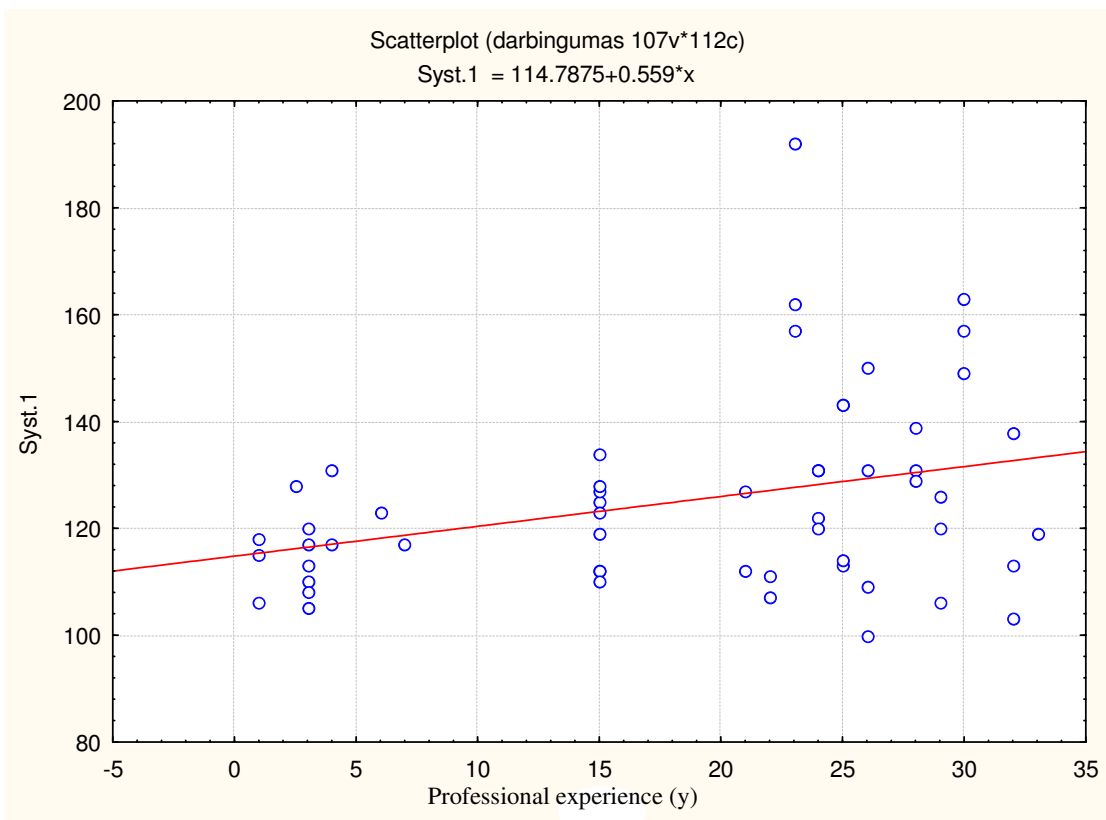

Fig 3. Professional experience (y) and arterial systolic blood pressure dependence 
Diastolic arterial pressure is blood pressure during diastole. The fluctuation of diastolic arterial pressure during the workday is shown in figure 4.

Diastolic blood pressure rose slightly yet stayed within normal limits. Established percentage of the hypertensive sizes: $17.6 \%$ on the first measurement; 18.2 $\%$ on the second one, $21.5 \%$ on the third measurement,
$21.3 \%$ on the fourth measurement, $20.7 \%$ on the fifth measurement, $28.6 \%$ on the sixth measurement, and 25 $\%$ on the seventh measurement. The average increase was $20.4 \%$. The diastolic pressure had the tendency to rise in comparison to the increase of systolic blood pressure; in addition, the elevation process started at the age of 41 and kept increasing with the age respectively (Fig 5).

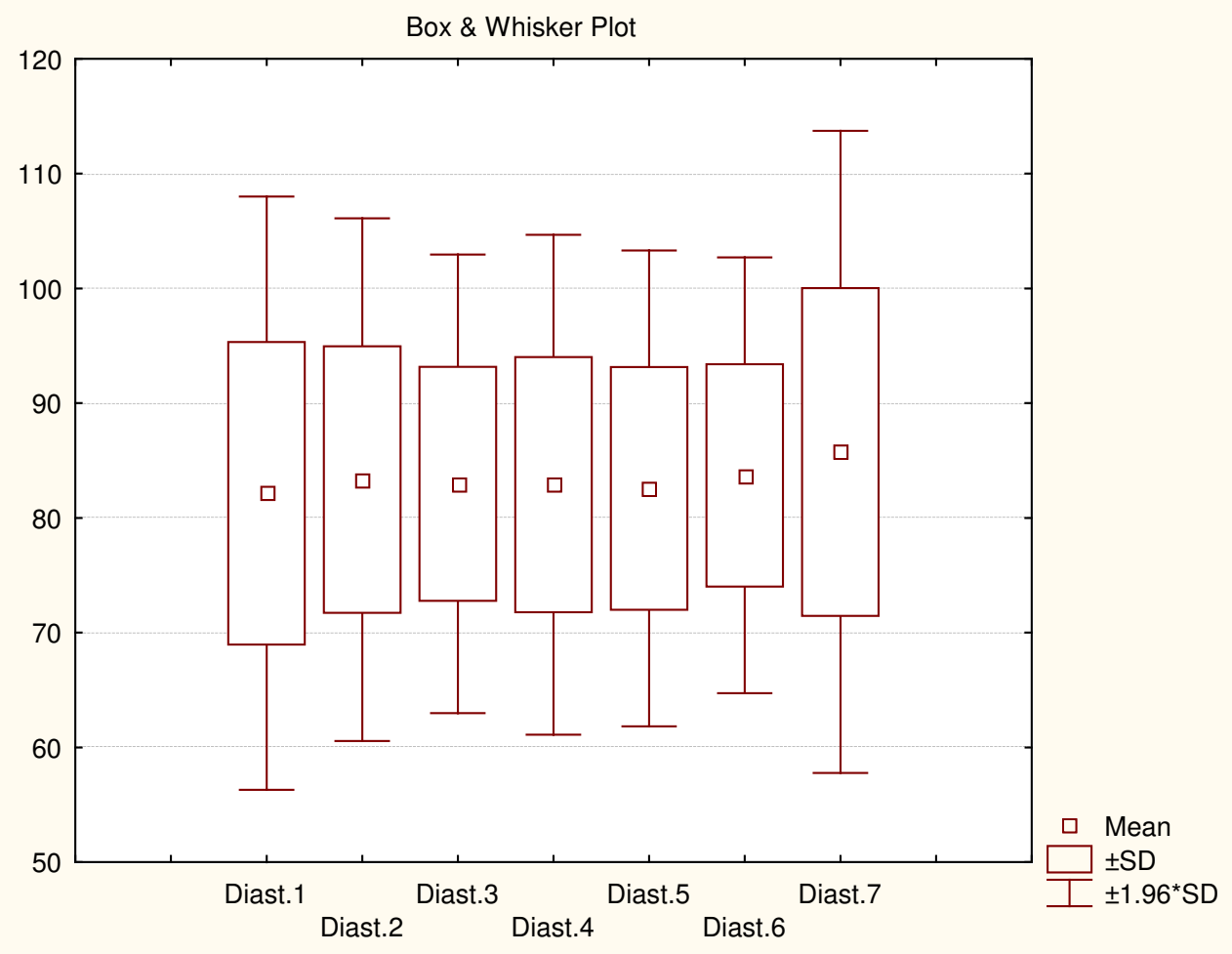

Fig 4. Variation in arterial diastolic blood pressure

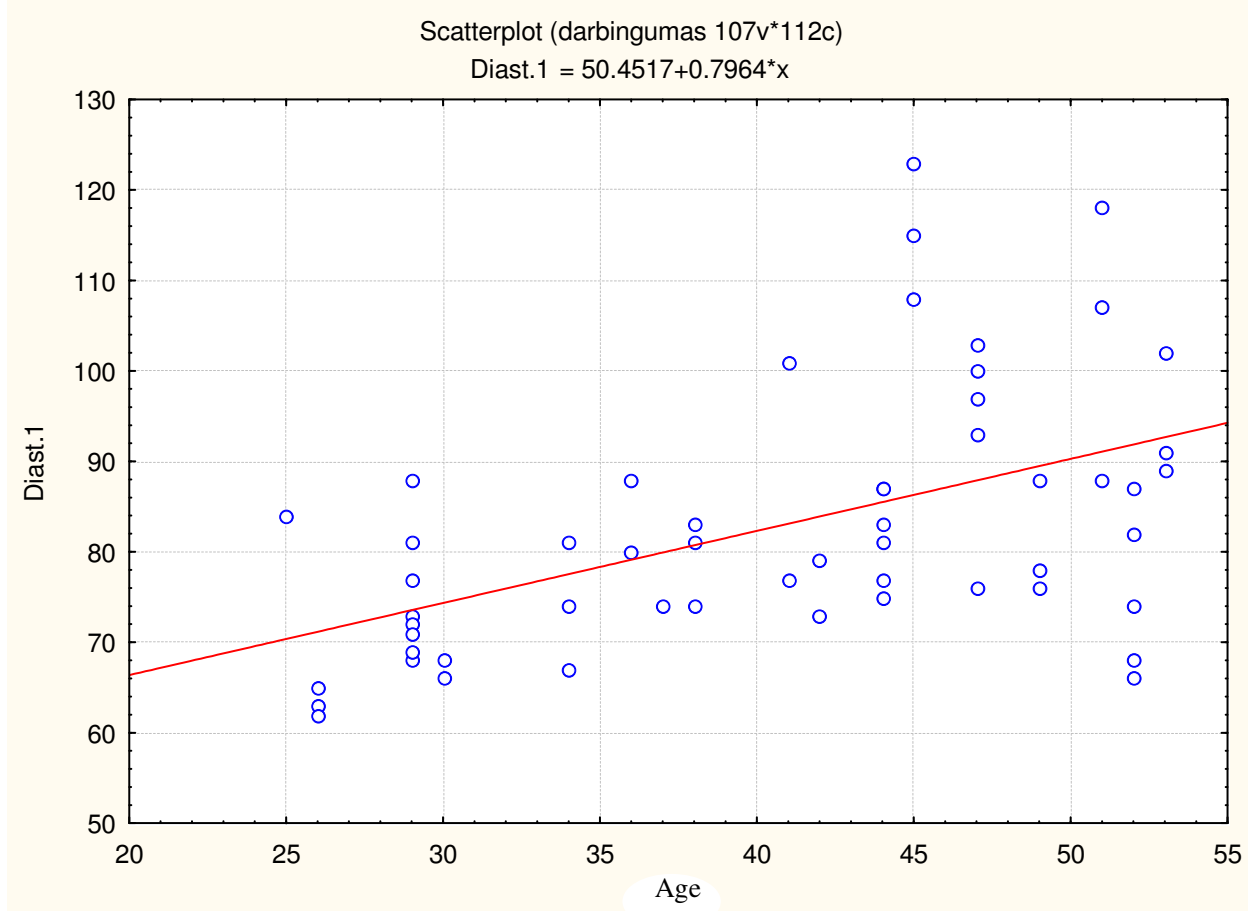

Fig 5. Age and arterial diastolic blood pressure dependence 
These results suggest that even in the normal workload conditions by peripheral vascular resistance and hyperkinetic hemodynamic changes begins. Such substantial changes with increasing professional work time have cause stable vascular spasm, whose conesquences - hemoperfusion deterioration of the brain, the brain hypoxia and mental reduction.

Heart rate variability is usually studied as a workload indicator. Heart rate as an indicator of stress at work reflects good overall response to the physical and mental stress, temperature, and/or the emotional stress. The heart rate increases with intensification of metabolic processes due to intensive mental and physical work. The heart rate rhythm usually returns back to a normal range fast if there is no more physical stress. Psychological stresses require a longer period for the heart rate to normalise though. See figure 6 below for the heart rate variation during the workday.

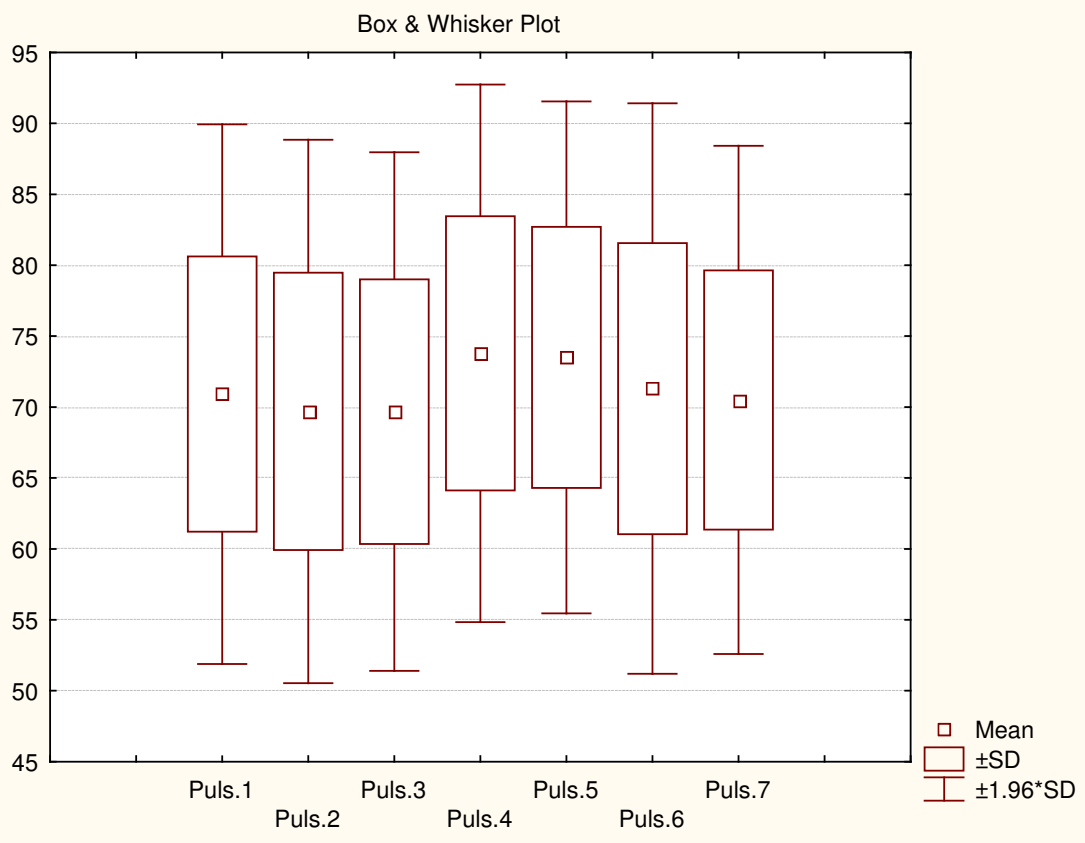

Fig 6. Variation in heart rate

Heart rate fluctuation is within normal limits. No statistically significant correlation between heart rate and age or heart rate and professional activity was found.
The influence of age on the cardio-vascular system is presented in the table below:

Relationship between age and cardiovascular system performance, measured at different periods of work

\begin{tabular}{|c|c|c|c|}
\hline $\begin{array}{c}\text { Time intervals in } \\
\text { measuring }\end{array}$ & $\begin{array}{c}\text { Arterial systolic blood } \\
\text { pressure }\end{array}$ & $\begin{array}{c}\text { Arterial diastolic blood } \\
\text { pressure }\end{array}$ & Heart rate \\
\hline Starting point & $\mathbf{0 . 3 5}$ & $\mathbf{0 . 5 0}$ & -0.00 \\
\hline After 2 hours & $\mathbf{0 . 3 7}$ & $\mathbf{0 . 5 4}$ & 0.14 \\
\hline After 4 hours & 0.27 & $\mathbf{0 . 4 0}$ & 0.06 \\
\hline After 6 hours & 0.16 & $\mathbf{0 . 4 5}$ & -0.07 \\
\hline After 8 hours & 0.26 & $\mathbf{0 . 2 3}$ & -0.22 \\
\hline After 10 hours & 0.26 & $\mathbf{0 . 3 9}$ & -0.04 \\
\hline After 12 hours & 0.17 & 0.34 & 0.11 \\
\hline
\end{tabular}

The highest correlation was found between age and arterial diastolic blood pressure. The analysis of psycho-physiological changes in air traffic controllers allows us to make the conclusion that daily professional activities did not cause significant changes in blood pressure or elevation in pulse rate. This could be the indicator of good professional training and skills.

\section{Conclusions}

The analysis of psycho-physiological indicators shows the following:

1. Arterial systolic blood pressure throughout the workday fluctuated slightly, and it varied depending on the professional experience of the participant.

2. Diastolic blood pressure had the tendency to rise more than systolic blood pressure. That kind of in- 
crease was noticed to have started in participants 41 years of age.

3. Heart rate fluctuated within normal limits.

\section{Recommendations}

In spite of minor psycho-physiological effects on the cardiovascular system, it is recommended:

- to inform air traffic controllers about the most common cardiovascular disease risk factors;

- to improve the health examination of air traffic control staff with the purpose of ascertaining early deviations from health standards.

\section{References}

Ammerman, H. L.; Bergen, D. K.; Hostetler, C. M. et al. 1987. FA Air traffic control operations concepts. In ARTCC/HOST En route controllers: vol. 6. Report number DOT/FAA/AP/86-01. Washington: Federal Aviation Administration.

Costa, G. 1993. Evaluation of workload in a group of air traffic controllers. Ergonomics, 36(9): 1111-1120.

Costa, G. 1995. Occupational stress and stress prevention in air traffic control. In Working paper CONDI/T/WP.6.
Farmer, E. W.; Belyavin, A. J.; Berry, A. et al. 1990. Stress in air traffic control. I. Survey of NATS controllers: Report No. 689. Farnborough: RAF Institute of Aviation Medicine.

Ming, E.; Adler, G.; Kessler, R., et al. 2004. Cardiovascular reactivity to work stress predicts subsequent onset of hypertension: the air traffic controller health change study. Psychosom Med. 66(4): 459-65.

Rose, R. M.; Jenkins, C. D.; Hurst, M. et al. 1982. Endocrine activity in air traffic controllers at work. Psychoneuroendocrinology, 7(2-3): 113123;

Sega, R.; Cesana, G.; Costa, G., et al. 1998. Ambulatory blood pressure in air traffic controllers. International Journal Occup Saf Ergon, 6(3): 365-82.

Smith, R. C. 1990. Stress, anxiety and the air traffic control specialist. In Stress in air traffic control. I. Survey of NATS controllers: Report No.FAA-AM-80-14. Washington: Federal Aviation Administration.

\section{SKRYDŽIŲ VADOVŲ KARDIOVASKULINĖS SISTEMOS RODIKLIŲ POKYČIŲ DARBO METU STUDIJA}

\section{Ereminas}

S a n trauka

Profesinio streso sukelti efektai sveikatai gali būti labai skirtingi, priklausomai nuo amžiaus, gyvenimo būdo, darbinès patirties, motyvacijos, fizinès ir psichinès sveikatos bei daugelio kitu veiksnių. Šio darbo tikslas yra ištirti VI „Oro navigacija“ dirbančiu skrydžiu vadovu darbo sukeliamus psichofiziologinius pokyčius.

Reikšminiai žodžiai: skrydžių vadovai, psichofiziologiniai pokyčiai, darbo krūvis. 